Article

\title{
Sustainability Reporting at a Crossroads in Italian Universities: Is Web-Based Media Adoption Deinstitutionalising Sustainability Reporting?
}

\author{
Patrizia Di Tullio * (D) and Matteo La Torre
}

Citation: Di Tullio, Patrizia, and Matteo La Torre. 2022. Sustainability Reporting at a Crossroads in Italian Universities: Is Web-Based Media Adoption Deinstitutionalising Sustainability Reporting? Administrative Sciences 12: 34. https://doi.org/10.3390/ admsci12010034

Received: 24 January 2022 Accepted: 15 February 2022 Published: 17 February 2022

Publisher's Note: MDPI stays neutral with regard to jurisdictional claims in published maps and institutional affiliations.

Copyright: (c) 2022 by the authors. Licensee MDPI, Basel, Switzerland. This article is an open access article distributed under the terms and conditions of the Creative Commons Attribution (CC BY) license (https:// creativecommons.org/licenses/by/ $4.0 /)$.

\author{
Department of Economic Studies, University "G. d'Annunzio" of Chieti-Pescara, 65122 Pescara, Italy; \\ matteo.latorre@unich.it \\ * Correspondence: patrizia.ditullio@unich.it
}

\begin{abstract}
Higher education institutions and universities have recently started to publish their sustainability and corporate responsibility reports. Yet, due to digitalisation and the benefits of digital reporting, websites offer organisations novel opportunities to communicate more updated, timely and interactive information than a periodic sustainability report. However, we know little about sustainability reporting practice within universities and their use of online communication. This study examines the relationship between sustainability reporting practices and web-based communication practices in Italian universities. We employed a qualitative enquire and content analysis of the sustainability web pages of Italian public universities by analysing their content and updates and their relationship with their adoption of sustainability reporting. Our results suggest there are risks to web-based media being used to replace sustainability reporting, resulting in a deinstitutionalising effect for sustainability reporting. This study contributes to the literature on sustainability reporting and disclosure in universities by exploring web-based university communication on sustainability issues and stimulating the debate on replacing sustainability reports with more timely and interactive forms of communication.
\end{abstract}

Keywords: sustainability; sustainability reporting; sustainability web pages; public sector; universities; Italian public universities; deinstitutionalisation

\section{Introduction}

As with other public organisations, universities have been subject to changing pressures over the recent decades. Initiatives for the corporatisation and commercialisation of universities, such as the introduction of calculative norms and standards, have fostered the adoption of new management techniques (Lapsley and Miller 2004; Larran Jorge and Pena 2017; Parker 2011). As a result, the reporting and accountability systems of universities have proliferated to present themselves and their performance externally through annual reports (Lapsley and Miller 2004; Martin-Sardesai et al. 2021; Parker 2011). Additionally, internal and external stakeholders have also demanded that universities demonstrate their contributions to sustainable development (Ceulemans et al. 2015). Therefore, over the last decade, universities have started to measure and account for the environmental and social impacts of their activities through sustainability reports (Alonso-Almeida et al. 2015; Moggi 2019).

Sustainability reports "are conceived as a tool for external accountability purposes, as well as for the management control system in universities" (Siboni et al. 2013, p. 2). A sustainability report is "the outcome of a collaborative process" (Adams 2013, p. 388). Therefore, the commitment of university management and technical staff is vital, and a low level of sustainability reporting adoption may reflect the poor management of sustainability in universities (Adams 2013; Christensen et al. 2009; Trireksani et al. 2021). According to Del 
Sordo et al. (2016), producing sustainability reports is not straightforward for universities, which is due to the lack of specific reporting standards and guidelines.

Prior research has identified some weaknesses in sustainability reports from universities. The reports are often used to disclose managerial aspects with little emphasis on environmental (Adams 2013; Siboni et al. 2013) and social (An et al. 2017; Lopatta and Jaeschke 2014; Sassen and Azizi 2018) issues. Universities have little knowledge of how to measure sustainability commitment in their three core missions (i.e., education, research and community involvement) (Adams 2013). Furthermore, sustainability reports are often prepared without the engagement of stakeholders and their static characteristic allows users little interaction (Ali et al. 2021; Ceulemans et al. 2015). Yet, universities have been exploring and using new media to communicate their sustainability commitments.

Digitalisation and the push for digital reporting has offered new ways to overcome the limits of paper-based reports and PDF files in sustainability reporting practice (La Torre et al. 2018). Sustainability information has been disclosed through different digital media, such as social media and the web, and in more flexible machine-readable language, such as HTML and XML (Locke et al. 2018). As a result, universities have been moving towards digitalising their reporting practice (Nicolò et al. 2021). They rely on websites to take advantage of their immediacy, create a sense of transparency and legitimise their image (Amey et al. 2020; Manes Rossi et al. 2018; Nicolò et al. 2021). Thus, sustainability information has been widely divulged through web pages or websites (Nicolò et al. 2021). However, exactly what universities communicate online about their sustainability efforts remains unknown (Amey et al. 2020; Ott et al. 2016) and prior studies have suggested investigating the use and content of university websites (Adhikariparajuli et al. 2021).

This study focused on Italian public universities and investigated the content of their web pages for sustainability information and their relationship with the adoption of sustainability reporting by employing a qualitative survey and content analysis. It aimed to assess the replacement of sustainability reporting with web-based communication. The analysis revealed four different approaches to adopting sustainability reporting and web-based communication by universities. These approaches suggest a latent risk of the deinstitutionalisation of sustainability reporting, which is often replaced by web-based media. This research contributes to the literature on sustainability in universities by exploring the web-based communication of universities regarding sustainability information and stimulating the debate on the potential replacement of sustainability reporting with more timely and interactive forms of communication.

This paper is structured as follows. Section 2 describes the research context and the literature within which this paper is positioned. We describe the research method in Section 3. Then, Section 4 presents our findings, while we discuss the results in Section 5. Section 6 presents our conclusions, along with the research limitations and recommendations for future research.

\section{Literature}

\subsection{Sustainability Reporting in Universities}

Universities can contribute to sustainable development and social change (Disterheft et al. 2013; Moggi 2019). Over recent years, several international initiatives, documents and declarations have highlighted the key role of universities in contributing to sustainable development, such as the Higher Education and Sustainability Initiative (HESI) (FerrerBalas et al. 2008; Lozano et al. 2013; Moggi 2019; Nicolò et al. 2021). In particular, universities have a pivotal role in promoting and achieving the Sustainable Development Goals (SDGs) (Arsenault 2021; Blasco et al. 2021; de La Poza et al. 2021; Leal Filho et al. 2019). The aim was to make the sustainability principles permeate all of their teaching, research and community involvement activities through a whole-institution approach (Amey et al. 2020; Arsenault 2021; Blasco et al. 2021; Del Sordo et al. 2016; Larran Jorge and Pena 2017). Therefore, the social dimension of the university goes beyond spatial barriers by reaching out to global communities (Mehta 2011; Vasilescu et al. 2010). 
Despite this acknowledgement, internal and external factors have influenced the approach of universities to sustainability and their adoption of sustainability reporting. Visionary leadership, the existence of research groups, coordinating units or sustainability scholars are some of the main internal factors (Ferrer-Balas et al. 2008; Fonseca et al. 2011; Larran Jorge et al. 2018). Meanwhile, institutional and stakeholder pressures are the main external factors (Fonseca et al. 2011; Lopatta and Jaeschke 2014; Manes Rossi et al. 2018). Specifically, university stakeholders, as with staff, students, public entities and alumni (Alonso-Almeida et al. 2015; Dade and Hassenzahl 2013), are increasingly demanding evidence of the university's contribution towards sustainable development (Aversano et al. 2020; Ceulemans et al. 2015). However, few universities have adopted sustainability reporting practice due to a lack of shared reporting tools and frameworks (Del Sordo et al. 2016; Moggi 2019; Sassen and Azizi 2017).

Fonseca et al. (2011, p. 25) state "how well the higher education sector is progressing towards sustainability remains a conundrum". The lack of databases offering comprehensive and updated collections of university sustainability reports has caused some difficulties in monitoring the trends of their adoption (Adams 2013; Moggi 2019). Furthermore, comparative analyses are challenging due to the different standards adopted by different universities (Adams 2013; Caputo et al. 2021). In this regard, there is an open debate around the adoption of the Global Reporting Initiatives (GRI) guidelines by universities. Several studies have considered the GRI guidelines as best suited for universities (Caputo et al. 2021; Yanez et al. 2019); others have highlighted that they were designed for business organisations rather than educational and scientific organisations (Amiano Bonatxea et al. 2021; Larran Jorge et al. 2018; Sepasi et al. 2019). Others have proposed to combine the GRI guidelines with other reporting guidelines to define a unique sustainability reporting framework for universities (Ceulemans et al. 2015). Therefore, there is still a need for an established and shared framework for sustainability reporting in universities.

The difficulties in adopting a sustainability reporting practice, the limitations of sustainability reports and the spread of online disclosure can result in the deinstitutionalisation of sustainability reporting. Deinstitutionalisation is defined as "the process by which the legitimacy of an established or institutionalised organisational practice erodes or discontinues" (Oliver 1992, p. 564). The drivers of deinstitutionalisation are political, functional and social pressures (Ball 2005; Oliver 1992). These pressures erode the validity or value of an institutionalised practice (Ball 2005). Sustainability reports are criticised for losing the importance and credibility of their information. Specifically, their information is essentially backwards looking and subject to manipulations, such that universities have often used sustainability reporting to legitimise themselves and gain acceptance (Ceulemans et al. 2015; Manes Rossi et al. 2018; Nicolò et al. 2021). Therefore, several studies have emphasised the need to go beyond traditional reporting tools by exploring new ways to provide the information to stakeholders (Manes Rossi et al. 2018; Sepasi et al. 2019; Yanez et al. 2019). Thus, there is a research interest in exploring the features and benefits of online sustainability disclosure.

\subsection{Universities Using Web-Based Communication for Sustainability Issues}

Nowadays, online presence is significant for companies and institutions (Bonsón and Ratkai 2013). The Internet is "a more effective disclosure instrument than the traditional communication media" (Ramírez and Tejada 2019). Web 2.0 technologies were "the next milestone in the evolution of corporate information" (Bonsón and Flores 2011, p. 34). Organisations could overcome the unidirectional communication model that characterises reports by using web 2.0 technologies (Bonsón and Flores 2011). Websites are Internetbased tools that are used to disclose activities and information to an international audience (Ramírez and Tejada 2019). They are the most commonly used medium to search for information and are used by organisations to communicate their responsibilities and improve their relationship with their stakeholders (Capriotti and Moreno 2007; Pisano et al. 2017; Ramírez and Tejada 2019). The public sector benefits from online communication 
because it improves the accessibility and timeliness of information being provided to stakeholders at a lower cost (Manes Rossi et al. 2018). In recent years, universities have moved towards the digitalisation of their service and reporting practices (Nicolò et al. 2021; Nardo et al. 2021; Trireksani et al. 2021), recognising that the Internet is a helpful tool in communicating their sustainability information to a large audience (Amey et al. 2020; Bonsón and Ratkai 2013; Dade and Hassenzahl 2013; Nicolò et al. 2021).

Universities have started to use websites to share their sustainability efforts, creating a sense of transparency and legitimising their actions within society (Nicolò et al. 2021; Ramírez and Tejada 2019). Their online presence is also a driver for promoting the SDGs among university stakeholders, showing their commitment to these goals and generating trust (Blasco et al. 2021). Websites also enhance interaction, networking and communication among the university community (Amey et al. 2020; An et al. 2017). The interactivity allowed by websites is enabled by comment sections, email subscription opportunities and surveys (Amey et al. 2020). Websites also have a more extensive reach; they are faster, cheaper, more updated and more informal than traditional communication media (Ramírez and Tejada 2019; Son-Turan and Lambrechts 2019). Therefore, through the use of web pages, universities can overcome the limits of stand-alone sustainability reports (An et al. 2017). However, the use of web technologies risks the replacement and deinstitutionalisation of sustainability reporting practice.

In practice, universities voluntarily communicate their sustainability information on their websites (Ramírez and Tejada 2019). Each university communicates a different set and amount of information that focuses on different sustainability aspects. Yet, previous studies have revealed that these websites contain little information, do not promote dialogue and interaction with stakeholders and do not adequately reflect the goals and activities of the university (Amey et al. 2020; Capriotti and Moreno 2007; Dade and Hassenzahl 2013). Therefore, according to Brusca et al. (2019), universities are not exploiting their websites' full potential and may only use them for a reputational rationale. Websites convey the essence of universities to stakeholders and are used to convince users to trust their services (Ramírez and Tejada 2019). However, Amey et al. (2020) argue that we still know little about how universities communicate their sustainability information online.

\subsection{Sustainability Reporting in Italian Universities}

Several studies have investigated the sustainability reporting practice of universities within single national contexts (Adhikariparajuli et al. 2021), e.g., Canada (Amey et al. 2020; Fonseca et al. 2011; Sassen and Azizi 2017) and the United States (Dade and Hassenzahl 2013; Ott et al. 2016; Sassen and Azizi 2018). Higher education systems are diverse worldwide and focusing on a single country may reveal how contextual institutions and norms influence the attitude of universities towards sustainability reporting (Amiano Bonatxea et al. 2021; Sassen et al. 2018).

Italy is considered an area of research interest given the growing pressures to adopt sustainability reporting in Italian universities. Italy has a long track record of sustainability and social reporting practices and a long wave of reforms that have changed the public sector (Aversano et al. 2020; Manes Rossi et al. 2018; Moggi 2019; Nicolò et al. 2021; Sangiorgi and Siboni 2017). Several studies have focused on the Italian university system (e.g., Aversano et al. 2020; Barnabè et al. 2014; Del Sordo et al. 2016; Siboni et al. 2013; Vagnoni and Cavicchi 2015) or on single case-study (e.g., Carrassi and Romanazzi 2007; Corazza 2018; Lombardi et al. 2019; Meneguzzo and Fiorani 2009; Mio 2013; Moggi et al. 2015). In particular, policymakers, organisations and associations have encouraged Italian public sector entities to adopt sustainability reports over the last two decades (Nicolò et al. 2021; Siboni et al. 2013).

The directive issued in 2006 by the Italian Minister for Public Affairs and the National Group for Social Reporting (GBS) provided some guidelines for universities regarding their sustainability reports (Del Sordo et al. 2016; Moggi 2019; Sangiorgi and Siboni 2017). However, these guidelines were principle-based and did not provide a list of indicators 
(Siboni et al. 2013). Furthermore, they were added to other existing international guidelines and tools, such as GRI's guidelines, the Sustainability Tracking, Assessment and Rating System and the Graphical Assessment of Sustainability in Universities (Del Sordo et al. 2016; Nicolò et al. 2021). Accordingly, these new guidelines may not resolve the heterogeneity of reporting practices among Italian universities. Recently, Italian universities have also started introducing SDG engagement and measurement in their communities. In this vein, the Council of Italian Rectors has promoted the creation of the Network of Universities for Sustainable Development (RUS in Italian) to drive the adoption of SDGs and spread best practice for sustainability policies (Nicolò et al. 2021).

Previous studies have highlighted some characteristics of the sustainability reporting practices in Italian universities. Italian universities developed different types of documents in terms of the structure, terminology and standards employed (Moggi 2019; Nicolò et al. 2021; Siboni et al. 2013). Sustainability reports are usually prepared by internal university staff and are not externally assured (Barnabè et al. 2014; Del Sordo et al. 2016; Moggi 2019). They grant limited importance to the social performance of the university and society issues while they focus on managerial issues (Del Sordo et al. 2016; Nicolò et al. 2021). Meanwhile, universities fail to engage stakeholders in the sustainability reporting process (Moggi et al. 2015). Thus, there are several limitations in the sustainability reporting practices of Italian universities.

In recent years, Italian universities have provided an increasing amount of information on their websites by creating website sections that are dedicated to sustainability (Manes Rossi et al. 2018; Nicolò et al. 2021). In contrast to sustainability reports, these university websites focus on social issues and the growth of human resources (Nicolò et al. 2021). As such, universities aim to overcome the limitations of stand-alone reports by visually communicating information on sustainability issues and facilitating dialogue with stakeholders (Nicolò et al. 2021).

\section{Method}

\subsection{Research Question}

This study analysed the structure and content of the sustainability web pages and websites of Italian universities to understand whether universities are making the most of the advantages that websites allow over sustainability reports in communicating their sustainability efforts. We also investigated whether and how the use of websites is associated with the adoption of sustainability reporting, thereby answering the following research question:

RQ: Is the adoption of web-based media deinstitutionalising sustainability reporting in Italian universities?

As a first step, we identified the universities with a sustainability web page or website. Then, the analysis focused on the content and structure of the website/web pages and the characteristics of the sustainability reporting practices.

\subsection{Sample Construction}

This study relies on data collection performed between April and May 2021 and focuses on Italian public universities. We selected public universities since they are more exposed to public pressures and are responsible for using public resources and showing public accountability; thus, we expected them to demonstrate a more significant commitment to sustainability reporting than private universities (Gallego et al. 2011; Larran Jorge et al. 2018). They also have different accounting requirements, funding sources and regulations from private and telematic universities (Aversano et al. 2020; Manes Rossi et al. 2018; Meneguzzo and Fiorani 2009). Nonetheless, public universities have a great relevance in the Italian university system in terms of their number of students, programs and disciplines (Vagnoni and Cavicchi 2015).

From the list created by CENSIS, an Italian socio-economic research institute, we selected an initial sample of 58 Italian public universities. We checked which of them have 
a sustainability landing page or website. According to Ott et al. (2016), "a sustainability landing page was defined as one that is clearly titled "sustainability" or one that refers to "sustainability" in the site title". Following this criterion, we found 37 universities that had sustainability landing pages or websites.

\subsection{Data Collection and Analysis}

We collected information on three aspects: the structural characteristics of the sustainability websites or web pages; the content of the sustainability websites or web pages; and the characteristics of the sustainability reporting practices.

In order to examine the characteristics of the sustainability websites or web pages, we analysed each university's website/web page to check whether sustainability information was included in a dedicated website or subsection and whether this page had been updated. Furthermore, we checked the website's structure in terms of the use of different subsections, multimedia and interactive tools (such as videos, questionnaires, surveys). This analysis resulted in a scheme through which we could check for the presence or absence of these elements.

To collect data about the content of sustainability websites, we employed the content analysis method. Content analysis "seeks to analyse published information systematically, objectively and reliably" (Guthrie et al. 2004, p. 287). It is widely used in accounting research to analyse corporate reporting practices (Dumay and Cai 2014). Recently, it has become popular in analysing university websites as well (Amey et al. 2020; Capriotti and Moreno 2007; Dade and Hassenzahl 2013; Manes Rossi et al. 2018). Following some previous studies (Manes Rossi et al. 2018; Ramírez and Tejada 2019), we only considered information from web pages in web-browser format, excluding any PDF documents that were published on the websites since they were separate information sources and were not coherent with the research purpose.

We analysed the content of the web pages through open coding. Text analysis consists of discovering themes that are "abstract constructs that link not only expressions found in texts but also expressions found in images" (Ryan and Bernard 2003, p. 87). Themes are "induced from empirical data" and are discovered through open coding (Ryan and Bernard 2003). Open coding requires observational techniques to look for themes in the text and manipulative techniques to process the texts (Ryan and Bernard 2003). We opted for repetition as an observational technique. Repetition assumes that "the more the same concept occurs in a text, the more likely it is a theme" (Ryan and Bernard 2003, p. 89). The investigator decided the number of repetitions needed to identify when a theme became significant for the research. We avoided biased classification by involving two researchers to sort the data together and name the piles to define the themes. As a result, we identified the following recurring sections: education and sustainability; research and sustainability; community involvement and sustainability; SDGs; activities and SDGs; stakeholders; and sustainability manager. Therefore, we checked for the presence or absence of this information.

Finally, we analysed the characteristics of sustainability reporting practices. First, for each university in our sample, we checked the link to, or the section for, sustainability reports and their publication within the last three years. Then, we read the sustainability reports and noted a list of their essential elements, such as the reporting period, the reporting guidelines adopted, the engagement of a report manager and verification by external auditors. The results are summarised in the tables in the next section.

\section{Results}

\subsection{University Sustainability Web Pages/Websites}

To understand the relationship between sustainability reporting and web-based communication and to answer the research question, we began our analysis with the structure and content of the university sustainability web pages/websites. The sample included universities of different sizes and from different geographical areas. While all of them 
communicated information about sustainability through web pages on their websites, we found that only 13 universities had a separate website dedicated to sustainability. Table 1 summarises the characteristics of the web pages and websites that we found.

Table 1. A summary of the structural characteristics of the sustainability web pages or websites.

\begin{tabular}{cccccc}
\hline & N. & Page Updated & $\begin{array}{c}\text { Structure into } \\
\text { Subsections }\end{array}$ & $\begin{array}{c}\text { Use of } \\
\text { Multimedia Tools } \\
\text { (Video) }\end{array}$ & $\begin{array}{c}\text { Use of Interactive Tools } \\
\text { (e.g., Questionnaires, } \\
\text { Surveys) }\end{array}$ \\
\hline $\begin{array}{c}\text { Web Page (i.e., Subsection } \\
\text { of the university website) }\end{array}$ & 24 & $42 \%$ & $71 \%$ & $25 \%$ & $25 \%$ \\
\hline Dedicated Website & 13 & $92 \%$ & $100 \%$ & $54 \%$ & $31 \%$ \\
\hline
\end{tabular}

The web pages/websites had a logical structure with different subsections covering different topics about sustainability and the activities promoted by the university. Universities with websites dedicated to sustainability were more prone to update their content, while we found that $58 \%$ of those with a web page failed to keep their content updated. Most of them did not use multimedia elements, such as videos, or interactive tools, such as questionnaires. Accordingly, few universities showed a section to collect user opinions or surveys about sustainability. Therefore, due to the lack of these dynamic characteristics, many websites generally appeared to be frozen showcases for the activities and initiatives of the universities.

Regarding the content of the web pages, we found that the universities focused most on sustainability topics in teaching (46\%) and research $(38 \%)$, and more rarely on community involvement activities (27\%). There was a lot of content and materials about seminars and massive open online courses (MOOC) organised by the universities and external partners. Furthermore, most universities described their courses and promoted awards for innovative theses focused on sustainability topics. Some universities also showed and described local and international research projects dedicated to sustainability initiatives, such as sustainable farming, social inclusion, climate change and research centre activities for sustainability and sustainable development. However, few universities disclosed their own sustainability efforts within the three core missions of teaching, research and community involvement.

Conversely, several universities (65\%) mentioned the SDGs and 2030 Agenda in their sustainability landing pages or dedicated websites. They explained the meaning of the 17 SDGs, showed videos, included podcasts and promoted events about SDGs. In particular, these events were organised by two associations: RUS and the Italian Alliance for Sustainable Development (ASviS in Italian). However, few universities (24\%) highlighted the link between their activities and courses programmes and the SDGs, with little evidence of them contributing to sustainable development and achieving the goals.

Since understanding stakeholder needs should be a central pillar for communicating their sustainable development commitments, some universities (8\%) created a section of their web page for listing the stakeholders and the type of information to which they refer. These lists included students (e.g., alumni, family of students), institutions and the external community (e.g., local and regional authorities, citizens, other universities), human resources (e.g., teaching and research staff, technical and administrative staff), media (e.g., journalists, press) and the environment. Furthermore, they specified how stakeholders are informed and engaged in sustainability activities. However, this was not a widespread practice as the universities rarely clarified to which stakeholders they were referring.

Most of the universities (62\%) provided information on the personnel or working group responsible for developing, promoting and coordinating the initiatives about sustainability. In many cases, a dedicated office within the organisation promoted initiatives for sustainability, the dissemination of good practice and communication campaigns to encourage public engagement. In these cases, there was a technical and administrative staff working on the sustainability commitment of the university. In other cases, there 
were academics, delegated by the Chancellor, who coordinated sustainability initiatives or particular tasks, such as managing the sustainability website, sustainable mobility program or energy management.

\subsection{The Relationship between Web Pages and Sustainability Reporting and the Deinstitutionalisation of Sustainability Reports}

Our results regarding web-based sustainability communication practices need to be related to sustainability reporting practices to understand how universities manage them and whether the adoption of web-based media is deinstitutionalising sustainability reporting in Italian universities.

Most of the universities in the sample published a sustainability report (24 out of 37). They usually included a link to download the sustainability reports in their landing pages or websites about sustainability. However, by deepening the relationship between the adoption of sustainability reporting and the use of web pages/websites, we found four different approaches used by the universities. Therefore, according to the following criteria and our evidence, we grouped the universities into the following four clusters:

- Cluster 1: "Sustainability web page adopters", including the universities that never adopted a sustainability report;

- Cluster 2: "Later adopters of sustainability reporting", including those who started adopting sustainability reporting in the last few years, publishing one or two reports in the last three years;

- Cluster 3: "Abandoners of sustainability reporting practice", including those who abandoned sustainability reporting and had their latest report published more than three years ago;

- Cluster 4: "Early adopters of sustainability reporting", including those who had a well-established and long-standing experience of sustainability reporting practice with more than two reports published overall and at least one in the last three years.

For each cluster, we checked some of the characteristics of the sustainability reporting practices, as shown in Table 2.

Cluster 1 ("sustainability web page adopters") was the largest and included universities that had never experienced the preparation of sustainability reports. However, while these universities dedicated a section of their website to sustainability, they rarely created a stand-alone website to communicate information about their sustainability initiatives. Furthermore, by cross-referencing the data in the web pages, we also found that most of these universities did not update their sustainability web pages nor used interactive tools, which are the main means to unfold the potential of web-based communication. For the universities in this cluster, sustainability reporting had never been an established practice; instead, they started to provide sustainability information through online communication. However, they had not yet established systematic web-based communication.

Cluster 2 ("later adopters of sustainability reporting") depicted a different approach. The universities in this cluster had recently approached sustainability reporting and published a sustainability report. Many adopted GRI reporting guidelines without an external audit. At the same time, the universities belonging to this cluster also had well-updated and articulated web pages to communicate their sustainability information. Thus, these universities had embarked on sustainability reporting and were also careful and active in communicating their sustainability information online. However, as with Cluster 1, these universities initially focused only on online communication. 
Table 2. A summary of reporting practices.

\begin{tabular}{|c|c|c|c|c|c|c|c|c|c|c|c|}
\hline Cluster & University & $\begin{array}{c}\text { Publication of } \\
\text { Sustainability } \\
\text { Report }\end{array}$ & $\begin{array}{c}\text { Link to or a } \\
\text { Section for } \\
\text { Sustainability } \\
\text { Report }\end{array}$ & $\begin{array}{l}\text { Publication of } \\
\text { Sustainability } \\
\text { Report in the } \\
\text { Last } 3 \text { Years }\end{array}$ & $\begin{array}{l}\text { Publication of } \\
\text { Sustainability } \\
\text { Reports for More } \\
\text { than a Year }\end{array}$ & $\begin{array}{l}\text { Number of } \\
\text { Years the } \\
\text { Reports Were } \\
\text { Published }\end{array}$ & $\begin{array}{l}\text { Reporting } \\
\text { Periods (Years } \\
\text { to Which the } \\
\text { Reports Refer) }\end{array}$ & $\begin{array}{c}\text { When the Latest } \\
\text { Reports Were } \\
\text { Published }\end{array}$ & $\begin{array}{l}\text { Reporting } \\
\text { Guidelines } \\
\text { Adopted }\end{array}$ & $\begin{array}{l}\text { External } \\
\text { Audit }\end{array}$ & $\begin{array}{c}\text { Report Man- } \\
\text { ager/Working } \\
\text { Group } \\
\text { Coordinator }\end{array}$ \\
\hline \multirow{10}{*}{$\begin{array}{c}\text { Cluster } 1 \\
\text { ("Sustainability } \\
\text { web page } \\
\text { adopters") }\end{array}$} & Messina & No & No & No & No & 0 & & & & & \\
\hline & Verona & No & No & No & No & 0 & & & & & \\
\hline & $\begin{array}{c}\text { Modena e } \\
\text { Reggio Emilia }\end{array}$ & No & No & No & No & 0 & & & & & \\
\hline & $\begin{array}{l}\text { Piemonte } \\
\text { Orientale }\end{array}$ & No & No & No & No & 0 & & & & & \\
\hline & Siena & No & No & No & No & 0 & & & & & \\
\hline & Catania & No & No & No & No & 0 & & & & & \\
\hline & Milano & No & No & No & No & 0 & & & & & \\
\hline & Cassino & No & No & No & No & 0 & & & & & \\
\hline & Teramo & No & No & No & No & 0 & & & & & \\
\hline & Bari & No & No & No & No & 0 & & & & & \\
\hline \multirow{9}{*}{$\begin{array}{c}\text { Cluster 2 } \\
\text { (“Later adopters of } \\
\text { sustainability } \\
\text { reporting") }\end{array}$} & Genova & Yes & Yes & Yes & No & 2 & 2018-2019; 2017 & $\begin{array}{c}\text { 2020; February } \\
2019\end{array}$ & GRI G4 & No & \\
\hline & Milano Bicocca & Yes & Yes & Yes & Yes & 2 & 2019, 2017 & $2021 ; 2019$ & GRI & No & \\
\hline & Parma & Yes & Yes & Yes & No & 1 & 2018 & December 2019 & GRI/GBS & No & \\
\hline & L'Aquila & Yes & No & Yes & No & 2 & 2014-2019; 2014 & $\begin{array}{l}\text { September 2019; } \\
\text { December } 2016\end{array}$ & $\begin{array}{l}\text { GBS (for the first } \\
\text { one only) }\end{array}$ & No & \\
\hline & Brescia & Yes & No & Yes & No & 1 & 2017-2019 & October 2020 & GRI & No & \\
\hline & Udine & Yes & Yes & Yes & Yes & 2 & $\begin{array}{l}\text { A.Y. 2018-2019; } \\
\text { 2017-2018 }\end{array}$ & $\begin{array}{l}\text { 2020; October } \\
2018\end{array}$ & No & No & $\begin{array}{c}\text { Professor } \\
\text { Garlatti }\end{array}$ \\
\hline & Trento & Yes & Yes & Yes & Yes & 2 & $\begin{array}{l}\text { 2020/2021; } \\
\text { 2016/2018; }\end{array}$ & $\begin{array}{l}\text { February 2020; } \\
\text { April 2017 }\end{array}$ & No & No & $\begin{array}{c}\text { Professor Marco } \\
\text { Ragazzi }\end{array}$ \\
\hline & Padova & Yes & Yes & Yes & Yes & 2 & 2019; 2018 & $\begin{array}{c}\text { October 2020; } \\
\text { December } 2019\end{array}$ & GRI & No & \\
\hline & Torino & Yes & Yes & Yes & Yes & 2 & $\begin{array}{l}\text { 2017-2019; } \\
\text { 2015-2016 }\end{array}$ & $\begin{array}{c}\text { December 2019; } \\
2016\end{array}$ & No & No & $\begin{array}{l}\text { Professor } \\
\text { Patrizia } \\
\text { Lombardi }\end{array}$ \\
\hline
\end{tabular}


Table 2. Cont.

\begin{tabular}{|c|c|c|c|c|c|c|c|c|c|c|c|}
\hline Cluster & University & $\begin{array}{c}\text { Publication of } \\
\text { Sustainability } \\
\text { Report }\end{array}$ & $\begin{array}{c}\text { Link to or a } \\
\text { Section for } \\
\text { Sustainability } \\
\text { Report }\end{array}$ & $\begin{array}{l}\text { Publication of } \\
\text { Sustainability } \\
\text { Report in the } \\
\text { Last } 3 \text { Years }\end{array}$ & $\begin{array}{c}\text { Publication of } \\
\text { Sustainability } \\
\text { Reports for More } \\
\text { than a Year }\end{array}$ & $\begin{array}{l}\text { Number of } \\
\text { Years the } \\
\text { Reports Were } \\
\text { Published }\end{array}$ & $\begin{array}{c}\text { Reporting } \\
\text { Periods (Years } \\
\text { to Which the } \\
\text { Reports Refer) }\end{array}$ & $\begin{array}{c}\text { When the Latest } \\
\text { Reports Were } \\
\text { Published }\end{array}$ & $\begin{array}{l}\text { Reporting } \\
\text { Guidelines } \\
\text { Adopted }\end{array}$ & $\begin{array}{c}\text { External } \\
\text { Audit }\end{array}$ & $\begin{array}{c}\text { Report Man- } \\
\text { ager/Working } \\
\text { Group } \\
\text { Coordinator }\end{array}$ \\
\hline \multirow{5}{*}{$\begin{array}{c}\text { Cluster } 3 \\
\text { ("Abandoners of } \\
\text { sustainability } \\
\text { reporting } \\
\text { practice") }\end{array}$} & Salerno & Yes & No & No & Yes & 4 & $\begin{array}{l}\text { 2013-2014; } \\
\text { 2011-2012; } \\
\text { 2009-2010; } \\
\text { 2007-2008 }\end{array}$ & $\begin{array}{c}\text { 2016; 2014; 2012; } \\
2010\end{array}$ & GBS & Yes & $\begin{array}{l}\text { Professor Marco } \\
\text { Pellicano }\end{array}$ \\
\hline & Pavia & Yes & No & No & No & 1 & 2007-2009 & 2010 & GBS & No & \\
\hline & Macerata & Yes & Yes & No & Yes & 6 & $\begin{array}{l}\text { 2012; 2011; 2010; } \\
\text { 2009; 2008; } 2007\end{array}$ & $\begin{array}{l}\text { 2013; 2012; 2011; } \\
\text { 2010; 2009; } 2008\end{array}$ & No & No & \\
\hline & Insubria & Yes & No & No & No & 1 & N.A. & March 2013 & & & \\
\hline & Foggia & Yes & Yes & No & No & 1 & A.Y. 2008-2009 & & No & No & \\
\hline \multirow{6}{*}{$\begin{array}{c}\text { Cluster } 4 \\
\text { (“Early adopters } \\
\text { of sustainability } \\
\text { reporting") }\end{array}$} & $\begin{array}{l}\text { Roma Tor } \\
\text { Vergata }\end{array}$ & Yes & Yes & Yes & Yes & 3 & $2019 ; 2018 ; 2017$ & 2020; 2019; 2018 & GRI & Yes & $\begin{array}{l}\text { Professor Marco } \\
\text { Meneguzzo }\end{array}$ \\
\hline & $\begin{array}{l}\text { Venezia Cà } \\
\text { Foscari }\end{array}$ & Yes & Yes & Yes & Yes & 10 & $\begin{array}{l}2019 ; 2018 ; 2017 ; \\
2016 ; 2015 ; 2014 ; \\
2013 ; 2012 ; 2011 ; \\
2010\end{array}$ & $\begin{array}{c}\text { 2020; October } \\
\text { 2019; 2018; July } \\
\text { 2017 }\end{array}$ & GRI $(2019 ; 2018)$ & No & $\begin{array}{l}\text { Professor Mio } \\
\text { Chiara }\end{array}$ \\
\hline & Marche & Yes & No & Yes & Yes & 3 & $2018 ; 2017 ; 2016$ & $\begin{array}{c}\text { October 31, 2019; } \\
\text { December 2018; } \\
2017\end{array}$ & GBS & No & $\begin{array}{c}\text { Professor } \\
\text { Chiucchi Serena }\end{array}$ \\
\hline & Torino & Yes & Yes & Yes & Yes & 6 & $\begin{array}{l}\text { 2018; 2017; 2016; } \\
\text { 2015; 2014; 2013 }\end{array}$ & $\begin{array}{c}\text { May 2020; } \\
\text { February 2018; } \\
\text { February 2017 }\end{array}$ & GRI & No & $\begin{array}{c}\text { Professor } \\
\text { Corazza Laura }\end{array}$ \\
\hline & $\begin{array}{l}\text { Roma La } \\
\text { Sapienza }\end{array}$ & Yes & Yes & Yes & Yes & 10 & $\begin{array}{l}\text { 2019; 2018; 2017; } \\
\text { 2016; 2015; 2014; } \\
\text { 2013; 2012; 2011; } \\
2010\end{array}$ & $\begin{array}{c}\text { October 2020; } \\
\text { 2019; 2018; } \\
\text { September 2017 }\end{array}$ & No & No & \\
\hline & Firenze & Yes & Yes & Yes & Yes & 4 & $\begin{array}{c}\text { 2019; 2018; 2017; } \\
\text { 2016 }\end{array}$ & $\begin{array}{c}\text { November 2020; } \\
\text { July 2019; } \\
\text { October } 2018\end{array}$ & GRI & No & $\begin{array}{c}\text { Professor } \\
\text { Manetti } \\
\text { Giacomo; } \\
\text { Professor } \\
\text { Bellucci Marco; } \\
\text { Professor } \\
\text { Bagnoli Luca } \\
\text { (for the 2017 } \\
\text { report) }\end{array}$ \\
\hline
\end{tabular}


Table 2. Cont.

\begin{tabular}{|c|c|c|c|c|c|c|c|c|c|c|c|}
\hline Cluster & University & $\begin{array}{c}\text { Publication of } \\
\text { Sustainability } \\
\text { Report }\end{array}$ & $\begin{array}{c}\text { Link to or a } \\
\text { Section for } \\
\text { Sustainability } \\
\text { Report }\end{array}$ & $\begin{array}{l}\text { Publication of } \\
\text { Sustainability } \\
\text { Report in the } \\
\text { Last } 3 \text { Years }\end{array}$ & $\begin{array}{c}\text { Publication of } \\
\text { Sustainability } \\
\text { Reports for More } \\
\text { than a Year }\end{array}$ & $\begin{array}{l}\text { Number of } \\
\text { Years the } \\
\text { Reports Were } \\
\text { Published }\end{array}$ & $\begin{array}{l}\text { Reporting } \\
\text { Periods (Years } \\
\text { to Which the } \\
\text { Reports Refer) }\end{array}$ & $\begin{array}{c}\text { When the Latest } \\
\text { Reports Were } \\
\text { Published }\end{array}$ & $\begin{array}{c}\text { Reporting } \\
\text { Guidelines } \\
\text { Adopted }\end{array}$ & $\begin{array}{c}\text { External } \\
\text { Audit }\end{array}$ & $\begin{array}{l}\text { Report Man- } \\
\text { ager/Working } \\
\text { Group } \\
\text { Coordinator }\end{array}$ \\
\hline \multirow{2}{*}{$\begin{array}{c}\text { Cluster } 4 \\
\text { ("Early adopters } \\
\text { of sustainability } \\
\text { reporting") }\end{array}$} & Pisa & Yes & Yes & Yes & Yes & 3 & $\begin{array}{r}\text { 2016-17; } \\
\text { 2014-15; } \\
\text { 2009-2012 }\end{array}$ & 2019; 2016; 2013 & $\begin{array}{l}\text { GRI (GBS for } \\
2013 \text { report) }\end{array}$ & No & $\begin{array}{c}\text { Professor Carlesi } \\
\text { Ada }\end{array}$ \\
\hline & Bologna & Yes & No & Yes & Yes & 8 & $\begin{array}{l}2019 ; 2018 ; 2017 ; \\
\text { 2016; 2015; 2014; } \\
\quad 2013 ; 2012\end{array}$ & $\begin{array}{c}\text { November 2020; } \\
\text { October 2019; } \\
\text { September 2018; } \\
\text { June } 2018\end{array}$ & GRI & No & \\
\hline
\end{tabular}


Conversely, the universities in Cluster 3 ("abandoners of sustainability reporting practice") abandoned their sustainability reporting practices in recent years in favour of web-based communication of their sustainability information. The sustainability reports published a few years ago were usually prepared without any guidelines or reporting framework, except for a few cases that used the GBS guidelines. They rarely indicated who was responsible for preparing the sustainability report or managing the whole sustainability reporting process. Half of them had a well-articulated and updated website or web page dedicated to sustainability. In contrast, the other half had a sustainability section that was not updated, structured into subsections and without any multimedia elements to promote user interaction. Hence, their abandonment of sustainability reporting practice resulted in its replacement with online communication or in abandoning both online communication and reporting practices.

The universities in Cluster 4 ("early adopters of sustainability reporting") had a well-established reporting practice that complemented and was supported by their online communication. Their reports were prepared according to the GRI reporting guidelines and they often indicated the report manager. However, even in these cases, the reports lacked external auditing. Almost all of the universities in this cluster also had a website dedicated to sustainability that had frequent updates and many multimedia and interactive tools. Therefore, this cluster demonstrated how the efforts to communicate sustainability information may leverage and benefit from the mutual enhancement between traditional and innovative means of divulging information.

\section{Discussion}

Most Italian universities have adopted a sustainability landing page or website to communicate their sustainability initiatives and efforts. According to Ott et al. (2016), a sustainability website indicates a strong commitment to sustainability communication. However, this commitment can also be driven by marketing advantages and external requirements (Ceulemans et al. 2015; Disterheft et al. 2013; Manes Rossi et al. 2018). For example, universities have been called upon to play a vital role in supporting the achievement of the SDGs (Arsenault 2021; Blasco et al. 2021; de La Poza et al. 2021; Leal Filho et al. 2019) and "the multidimensional character of the SDGs underlines the need to conduct specific reflections on them" (Caputo et al. 2021, p. 9). Instead, several universities mention the SDGs and 2030 Agenda but do not go beyond creating a showcase for definitions and events about the SDGs. Accordingly, this way of communicating sustainability information may be only extemporaneous and may not enact a continuous and pervasive reporting process within the organisations.

Our findings support previous research confirming that universities are not fully exploiting the potential of websites due to the lack of the use of multimedia and interactive tools for increasing engagement (Brusca et al. 2019). This lack could be the result of several reasons, such as the lack of technical facilities to continuously create and manage interactive tools or the need for financial and human resources (Amey et al. 2020). Managing information and defining sustainability content for websites is a complex task. Universities need dedicated staff to manage the communication of their sustainability efforts and initiatives (Trireksani et al. 2021). According to Moggi et al. (2015, p. 94), the role of "a person who has a research interest or a personal inclination" in sustainability topics and accountability play a pivotal role. Therefore, having human resources with knowledge and expertise in sustainability topics can be a driver in promoting and establishing communication with stakeholders about sustainability.

Moreover, the web pages are rarely updated and enriched with new content. The inability to exploit this potential makes the websites a merely unidirectional communication medium, just as a sustainability report can be. Therefore, web-based sustainability communication by universities does not seem to be a way to overcome the limitations of stand-alone sustainability reports. In turn, using websites is a way to adopt a faster, cheaper and more informal communication compared to traditional media (Ramírez and Tejada 2019). Adopt- 
ing sustainability reporting would be more costly and time-consuming and would require a more significant effort than creating a web page (Son-Turan and Lambrechts 2019).

Regarding the relationship between sustainability web pages and sustainability reporting, we found four different approaches that were used by the universities that we classified into four clusters (see Table 2). The universities in the first cluster ("sustainability web page adopters") never published a sustainability report but did create a sustainability web page. Most of them did not handle the web page content frequently, resulting in episodic communication and a short-term purpose in using the web page. Therefore, they likely created the website or web page due to external pressures, such as the public spotlight on sustainability issues.

Despite that, they did not show any plan to start adopting a sustainability report in the near future. This approach may be due to the lack of specific guidelines for sustainability reporting in universities and the lack of dedicated staff to manage the sustainability information and communication. In this case, adopting web-based media for sustainability communication appears to be more of a prompt response to a compelling need rather than the result of an established internal process for sustainability reporting. The recent advances in the RUS and GBS guidelines for sustainability reporting in universities (RUS and GBS 2021) may encourage these universities to adopt sustainability reporting.

Cluster 2 ("later adopters of sustainability reporting") included those universities that started to publish a sustainability report in the last few years and, at the same time, had discovered the advantage of using a web-based means for sustainability communication. They likely adopted the sustainability reporting practice to satisfy external stakeholder needs by using well-established reporting guidelines and involving scholars and administrative staff in this practice. These universities could be exposed to a learning process whereby the activities required for online sustainability communication could become a precondition to adopt and prepare a sustainability report. They could leverage the skills and expertise from managing the content of websites (e.g., the collection and management of sustainability information) to prepare sustainability reports.

In the third cluster ("abandoners of sustainability reporting practice"), universities abandoned sustainability reporting in favour of web-based communication. In these cases, they replaced their sustainability reports with web pages or websites dedicated to sustainability. This replacement could be explained by the will to use a cheaper communication media that requires less effort, commitment and capability than sustainability reporting (Manes Rossi et al. 2018; Ramírez and Tejada 2019). However, replacing sustainability reports should imply a significant endeavour in online communication. Websites and web pages should be frequently updated with timely information about the university's commitment to sustainability within its three main missions. Static pages and insufficient information are not able to meet the information needs of stakeholders.

Cluster 4 ("early adopters of sustainability reporting") represented the virtuous cases. The universities in this cluster had a well-established sustainability reporting practice and a well-structured and updated web page/website that was dedicated to sustainability (see Table 2). They had a well-established process and staff with the necessary knowledge and skills to manage the information and steer them in different communication channels. This result confirms the vital role of university staff in sustainability reporting practices (Christensen et al. 2009; Larran Jorge et al. 2018).

In sum, our study demonstrates a move away from sustainability reporting practices, which creates the risk of the deinstitutionalisation of this practice. The "sustainability web page adopters" and the "abandoners of sustainability reporting practice" are evidence of this replacement of sustainability reporting with web-based communication. However, it is our opinion that web-based media for sustainability communication cannot replace sustainability reporting in the pursuit of the accountability of the university stakeholders. Web-based communication can provide timely and more practical information. Yet, it cannot enable the same learning processes and internal engagement that result from sustainability reporting. The sustainability report is not merely a document; instead, 
it is the result of a complex process that involves internal structures and procedures and requires the establishment of internal processes and the engagement and commitment of internal and external actors (Adams and Frost 2008; Capocchi et al. 2019; Sassen and Azizi 2017). Sustainability reporting may result in a learning cycle as organisations gradually improve their expertise in managing sustainability in the organisation (Adams and Frost 2008; Herremans et al. 2016; Moggi 2019).

At the same time, our findings demonstrate that adopting both web-based media and traditional reporting can enact a mutually enhancing effect. The "later adopters of sustainability reporting" used the experience gained through online reporting to prepare their sustainability reports. In turn, the universities with a long tradition of sustainability reporting (i.e., the "early adopters of sustainability reporting") started to complement this with web-based communication. However, these findings also highlight that universities are moving away from using sustainability reports as a primary means to communicate their sustainability information externally. Using web-based communication offers some advantages, such as lower costs and timely communication. These functional pressures (Ball 2005; Oliver 1992) may erode the value of sustainability reporting, which, in turn, could fall into deinstitutionalisation.

\section{Conclusions}

This paper analysed the web-based sustainability communication of Italian public universities and the characteristics of their sustainability reporting practices. By deepening the relationship between sustainability web pages and sustainability reporting, we aimed to unveil whether web-based media are replacing sustainability reporting and thereby causing the risk of the deinstitutionalisation of sustainability reporting practices.

The study offered novel opportunities for research and practice. It increased our understanding of how Italian public universities communicate their sustainability initiatives and efforts. Furthermore, it provided an overview of sustainability reporting practices, showing the risk of their deinstitutionalisation. Universities may reflect on the unexploited potentials offered by web-based media to engage stakeholders in the sustainability reporting process and foster communication on sustainability issues. They may also become aware of the importance of structures and staff that are dedicated to communicating and reporting their sustainability initiatives.

One limitation of this study lies in providing only a snapshot of the current practices of universities in communicating their sustainability information. Meanwhile, universities might have changed their approach to sustainability reporting and web-based communication by changing their position within the four clusters we identified. Furthermore, the recent guidelines for sustainability reporting in universities by RUS and GBS may contribute to this change. Thus, future studies can enrich our understanding of the adoption of sustainability reporting in universities and how their approaches to sustainability reporting and communication may evolve.

As this study only referred to Italian universities and provided evidence from a national context, future research could examine other national and cultural contexts to enrich our findings and provide further insights from an international perspective. Furthermore, this research only considered public universities. According to Zorio-Grima et al. (2018), focusing on public universities is a common limitation in the literature about sustainability reporting in universities. Future studies may overcome this limitation by including and examining private universities in their research.

Many universities have started integrating sustainability principles into their strategic planning documents (Caputo et al. 2021; Di Nauta et al. 2020; Fantauzzi et al. 2021; Lombardi et al. 2019). Accordingly, future research into how sustainability merges into and influences other documents and activities could extend our knowledge of the media being used for sustainability communication and the reporting that is being adopted by universities. Similarly, this research could be enriched by investigating the contributions of other online Internet tools, such as social media, that are dedicated to sustainability in 
overcoming the limitations of sustainability reports and enabling stakeholder engagement (Di Tullio et al. 2021).

Author Contributions: Conceptualization: P.D.T., M.L.T.; Literature review: P.D.T.; Methodology: P.D.T. \& M.L.T.; Data curation: P.D.T.; Discussion: P.D.T. \& M.L.T.; writing—original draft preparation P.D.T. \& M.L.T.; writing-review and editing P.D.T. \& M.L.T. All authors have read and agreed to the published version of the manuscript.

Funding: This research received no external funding.

Informed Consent Statement: Not applicable.

Data Availability Statement: Not applicable.

Conflicts of Interest: The authors declare no conflict of interest.

\section{References}

Adams, Carol. 2013. Sustainability reporting and performance management in universities. Sustainability Accounting, Management and Policy Journal 4: 384-92. [CrossRef]

Adams, Carol, and Geoffrey Frost. 2008. Integrating sustainability reporting into management practices. Accounting Forum 32: $288-302$. [CrossRef]

Adhikariparajuli, Mahalaxmi, Abeer Hassan, and Benedetta Siboni. 2021. CSR Implication and Disclosure in Higher Education: Uncovered Points. Results from a Systematic Literature Review and Agenda for Future Research. Sustainability 13: 525. [CrossRef]

Ali, Muhammad, Ishamuddin Mustapha, Sharina Binti Osman, and Umar Hassan. 2021. University social responsibility: A review of conceptual evolution and its thematic analysis. Journal of Cleaner Production 286: 124931. [CrossRef]

Alonso-Almeida, Maria, Fredreric Marimon, Fernando Casanni, and Jesus Rodriguez-Pomeda. 2015. Diffusion of sustainability reporting in universities: Current situation and future perspectives. Journal of Cleaner Production 106: 144-54. [CrossRef]

Amey, Leaya, Ryan Plummer, and Gary Pickering. 2020. Website communications for campus sustainability: An analysis of Canadian universities. International Journal of Sustainability in Higher Education 21: 531-56. [CrossRef]

Amiano Bonatxea, Iratxe, Jorge Gutierrez-Goiria, Maria Jose Vazquez-De Francisco, and Antonio Sianes. 2021. Is the global reporting initiative suitable to account for university social responsibility? Evidence from European institutions. International Journal of Sustainability in Higher Education. [CrossRef]

An, Yi, Howard Davey, and Harun Harun. 2017. Sustainability Reporting at a New Zealand Public University: A Longitudinal Analysis. Sustainability 9: 1529. [CrossRef]

Arsenault, Nicole. 2021. The Role of Universities towards a Sustainable Future: Integrating the Sustainable Development Goals. Available online: http:/ / hdl.handle.net/10315/38961 (accessed on 15 December 2021).

Aversano, Natalia, Ferdinando Di Carlo, Giuseppe Sannino, Paolo Tartaglia Polcini, and Rosa Lombardi. 2020. Corporate social responsibility, stakeholder engagement, and universities: New evidence from the Italian scenario. Corporate Social Responsibility and Environmental Management 27: 1892-99. [CrossRef]

Ball, Amanda. 2005. Environmental accounting and change in UK local government. Accounting, Auditing \& Accountability Journal 18: 346-73.

Barnabè, Federico, Maria Giorgino, and Sergio Paternostro. 2014. Il ruolo del Bilancio Sociale nelle Università pubbliche italiane: Una riflessione sullo stato dell'arte. Azienda Pubblica 1: 58-80.

Blasco, Natividad, Isabel Brusca, and Margarita Labrador. 2021. Drivers for universities' contribution to the sustainable development goals: An analysis of Spanish public universities. Sustainability 13: 89. [CrossRef]

Bonsón, Enrique, and Francisco Flores. 2011. Social media and corporate dialogue: The response of global financial institutions. Online Information Review 35: 34-49. [CrossRef]

Bonsón, Enrique, and Melinda Ratkai. 2013. A set of metrics to assess stakeholder engagement and social legitimacy on a corporate Facebook page. Online Information Review 37: 787-803. [CrossRef]

Brusca, Isabel, Sandra Cohen, Francesca Manes-Rossi, and Giuseppe Nicolò. 2019. Intellectual capital disclosure and academic rankings in European universities. Meditari Accountancy Research 28: 51-71. [CrossRef]

Capocchi, Alessandro, Paola Orlandini, Cinzia Vallone, Murad Harasheh, and Stefano Amelio. 2019. The Important Role of Universities in Enhancing Sustainability: The Case of the University of Milano-Bicocca. In Social Responsibility and Sustainability: How Businesses and Organisations Can Operate in a Sustainable and Socially Responsible Way. Edited by W. Leal Filho. Berlin and Heidelberg: Springer, pp. 389-410.

Capriotti, Paul, and Ángeles Moreno. 2007. Corporate citizenship and public relations: The importance and interactivity of social responsibility issues on corporate websites. Public Relations Review 33: 84-91. [CrossRef]

Caputo, Fabio, Lorenzo Ligorio, and Simone Pizzi. 2021. The Contribution of Higher Education Institutions to the SDGs-An Evaluation of Sustainability Reporting Practices. Administrative Sciences 11: 97. [CrossRef] 
Carrassi, Mario, and Salvatore Romanazzi. 2007. La rendicontazione sociale nell'università: L'esperienza dell'Università di Bari. In Lo Standard G.B.S. per la Rendicontazione Sociale Nella Pubblica Amministrazione. Edited by P. Ricci. Milano: Riflessioni a Confronto, Franco Angeli.

Ceulemans, Kim, Ingrid Molderez, and Luc Van Liedekerke. 2015. Sustainability reporting in higher education: A comprehensive review of the recent literature and paths for further research. Journal of Cleaner Production 106: 127-43. [CrossRef]

Christensen, Per, Mikkel Thrane, Tine Herreborg Jørgensen, and Martin Lehmann. 2009. Sustainable development. International Journal of Sustainability in Higher Education 10: 4-20. [CrossRef]

Corazza, Laura. 2018. The process of social accounting and reporting at University of Torino: Main challenges and managerial implications. World Review of Entrepreneurship, Management and Sustainable Development 14: 171-86. [CrossRef]

Dade, Auralì, and David M. Hassenzahl. 2013. Communicating sustainability: A content analysis of website communications in the United States. International Journal of Sustainability in Higher Education 14: 254-63. [CrossRef]

de La Poza, Elena, Paloma Merello, Antonio Barberá, and Alberto Celani. 2021. Universities' reporting on SDGs: Using the impact rankings to model and measure their contribution to sustainability. Sustainability 13: 2038. [CrossRef]

Del Sordo, Carlotta, Federica Farneti, James Guthrie, Silvia Pazzi, and Benedetta Siboni. 2016. Social reports in Italian universities: Disclosures and preparers' perspective. Meditari Accountancy Research 24: 91-110. [CrossRef]

Di Nauta, Primiano, Enrica Iannuzzi, Michele Milone, and Claudio Nigro. 2020. The Impact of the Sustainability Principles on the Strategic Planning and Reporting of Universities. An Exploratory Study on a Qualified Italian Sample. Sustainability 12: 7269. [CrossRef]

Di Tullio, Patrizia, Matteo La Torre, and Michele Antonio Rea. 2021. Social media for engaging and educating: From universities' sustainability reporting to dialogic communication. Administrative Science 11: 151. [CrossRef]

Disterheft, Antje, Sandra Caeiro, and Ulisses Miranda Azeiteiro. 2013. Sustainability Science and Education for Sustainable Development in Universities: A Way for Transition. In Sustainability Assessment Tools in Higher Education Institutions. Edited by Sandra Caeiro, Walter Leal Filho, Charbel Jabbour and Ulisses M. Azeiteiro. New York: Springer International Publishing, pp. 3-27.

Dumay, John, and Linlin Cai. 2014. A review and critique of content analysis as a methodology for inquiring into IC disclosure. Journal of Intellectual Capital 15: 264-90. [CrossRef]

Fantauzzi, Chiara, Nathalie Colasanti, Gloria Fiorani, and Rocco Frondizi. 2021. Sustainable strategic planning in Italian higher education institutions: A content analysis. International Journal of Sustainability in Higher Education 22: 1145-65. [CrossRef]

Ferrer-Balas, Didac, Jun Adachi, S. Banas, C. I. Davidson, A. Hoshikoshi, Arabinda Mishra, Y. Motodoa, M. Onga, and Madalene Ostwald. 2008. An international comparative analysis of sustainability transformation across seven universities. International Journal of Sustainability in Higher Education 9: 295-316. [CrossRef]

Fonseca, Alberto, Amanda Macdonald, Emily Dandy, and Paul Valenti. 2011. The state of sustainability reporting at Canadian universities. International Journal of Sustainability in Higher Education 12: 22-40. [CrossRef]

Gallego, Isabel, Luis Rodriguez, and Isabel Maria Garcia. 2011. Information disclosed online by Spanish Universities: Content and explanatory factors. Online Information Review 35: 360-85. [CrossRef]

Guthrie, James, Richard Petty, K. Yongvanich, and Federica Ricceri. 2004. Using content analysis as a research method to inquire into intellectual capital reporting. Journal of Intellectual Capital 5: 282-93. [CrossRef]

Herremans, Irene, Jamal Nazari, and Fereshteh Mahmoudian. 2016. Stakeholder Relationships, Engagement, and Sustainability Reporting. Journal of Business Ethics 138: 417-35. [CrossRef]

La Torre, Matteo, Vida Botes, John Dumay, Michele Antonio Rea, and Elza Odendaal. 2018. The fall and rise of intellectual capital accounting: New prospects from the Big Data revolution. Meditari Accountancy Research 26: 381-99. [CrossRef]

Lapsley, Irvine, and Peter Miller. 2004. Foreword: Transforming Universities: The Uncertain, Erratic Path. Financial Accountability and Management 20: 103-6. [CrossRef]

Larran Jorge, Manuel, and Francisco Pena. 2017. Analysing the literature on university social responsibility: A review of selected higher education journals. Higher Education Quarterly 71: 302-19. [CrossRef]

Larran Jorge, Manuel, Francisco Pena, and J. Herrera Madueno. 2018. An analysis of university sustainability reports from the GRI database: An examination of influential variables. Journal of Environmental Planning and Management 62: 1019-44. [CrossRef]

Leal Filho, Walter, Chris Shiel, Arminda Paço, Mark Mifsud, Lucas Veiga Ávila, Luciana Londero Brandli, Petra Molthan-Hill, Paul Pace, Ulisses Azeiteiro, Valeria Ruiz Vargas, and et al. 2019. Sustainable Development Goals and sustainability teaching at universities: Falling behind or getting ahead of the pack? Journal of Cleaner Production 232: 285-94. [CrossRef]

Locke, Joanne, Nick Rowbottom, and Indrit Troshani. 2018. Sites of translation in digital reporting. Accounting, Auditing E Accountability Journal 31: 2006-30.

Lombardi, Rosa, Maurizio Massaro, John Dumay, and Fabio Nappo. 2019. Entrepreneurial universities and strategy: The case of the University of Bari. Management Decision 57: 3387-405. [CrossRef]

Lopatta, Kerstin, and Reemda Jaeschke. 2014. Sustainability reporting at German and Austrian universities. International Journal of Education Economics and Development 5: 67-90. [CrossRef]

Lozano, Rodrigo, Rebeka Lukman, Francisco Lozano, and Donald Huisingh. 2013. Declarations for sustainability in higher education: Becoming better leaders, through addressing the university system. Journal of Cleaner Production 48: 10-19. [CrossRef]

Manes Rossi, Francesca, Giuseppe Nicolò, and Paolo Tartaglia Polcini. 2018. New trends in intellectual capital reporting: Exploring online intellectual capital disclosure in Italian universities. Journal of Intellectual Capital 19: 814-35. [CrossRef] 
Martin-Sardesai, Ann, James Guthrie, and Lee Parker. 2021. The neoliberal reality of higher education in Australia: How accountingisation is corporatising knowledge. Meditari Accountancy Research 29: 1261-82. [CrossRef]

Mehta, Sandhya Rao. 2011. Corporate Social Responsibility (CSR) and Universities: Towards an Integrative Approach. International Journal of Social Science and Humanity 1: 300-4. [CrossRef]

Meneguzzo, Marco, and Gloria Fiorani. 2009. Scelte di sviluppo, innovazione organizzativa e rendicontazione sociale: Il bilancio di mandato dell'Università degli Studi di Roma Tor Vergata. Rivista Italiana di Ragioneria e di Economia Aziendale 109: $347-59$.

Mio, Chiara. 2013. Towards a Sustainable University: The Ca' Foscari Experience. New York: Palgrave Pivot.

Moggi, Sara. 2019. Social and environmental reports at universities: A Habermasian view on their evolution. Accounting Forum 43: 283-26. [CrossRef]

Moggi, Sara, Chiara Leardini, and Bettina Campedelli. 2015. Social and Environmental Reporting in the Italian Higher Education System: Evidence from Two Best Practices. In Integrative Approaches to Sustainable Development at University Level, World Sustainability Series. Edited by Walter Leal Filho, Luciana Brandli, Arminda Maria Finisterra do Paco and Olga Kuznestsova. New York: Springer International Publishing, pp. 81-96.

Nardo, Maria, Roberto Maglio, Fabiana Roberto, Francesco Agliata, and Andrea Rey. 2021. Intellectual Capital and the Role of Technologies in Public Universities: A Case Study Analysis. In Intellectual Capital, Smart Technologies and Digitalization. SIDREA Series in Accounting and Business Administration. Edited by Maria Serena Chiucchi, Rosa Lombardi and Daniela Mancini. Cham: Springer.

Nicolò, Giuseppe, Natalia Aversano, Giuseppe Sannino, and Paolo Tartaglia Polcini. 2021. Investigating web-based sustainability reporting in Italian public universities in the era of Covid-19. Sustainability 13: 3468. [CrossRef]

Oliver, Christine. 1992. The antecedents of deinstitutionalization. Organization Studies 13: 563-88. [CrossRef]

Ott, Holly, Ruoxu Wang, and Denise Bortree. 2016. Communicating Sustainability Online: An Examination of Corporate, Nonprofit, and University Websites. Mass Communication and Society 19: 671-87. [CrossRef]

Parker, Lee. 2011. University corporatisation: Driving redefinition. Critical Perspectives on Accounting 22: 434-50. [CrossRef]

Pisano, Sabrina, Luigi Lepore, and Rita Lamboglia. 2017. Corporate disclosure of human capital via LinkedIn and ownership structure. Journal of Intellectual Capital 18: 102-27. [CrossRef]

Ramírez, Yolanda, and Ángel Tejada. 2019. Digital transparency and public accountability in Spanish universities in online media. Journal of Intellectual Capital 20: 701-32. [CrossRef]

RUS, and GBS. 2021. Il Bilancio di Sostenibilità delle Università. Standard RUS-GBS. Available online: https:/ / reterus.it/public/files / Documenti/altri_documenti_RUS/RUS-GBS-standard_DEF.pdf (accessed on 1 November 2021).

Ryan, Gery, and Russell Bernard. 2003. Techniques to Identify Themes. Field Methods 15: 85-109. [CrossRef]

Sangiorgi, Daniela, and Benedetta Siboni. 2017. The disclosure of intellectual capital in Italian universities: What has been done and what should be done. Journal of Intellectual Capital 18: 354-72. [CrossRef]

Sassen, Remmer, and Leyla Azizi. 2017. Voluntary disclosure of sustainability reports by Canadian universities. Journal of Business Economics 88: 97-137. [CrossRef]

Sassen, Remmer, and Leyla Azizi. 2018. Assessing sustainability reports of US universities. International Journal of Sustainability in Higher Education 19: 1158-84. [CrossRef]

Sassen, Remmer, Dominik Dienes, and Johanna Wedemeier. 2018. Characteristics of UK higher education institutions that disclose sustainability reports. International Journal of Sustainability in Higher Education 19: 1279-98. [CrossRef]

Sepasi, Sahar, Udo Braendle, and Amir Hossein Rahdari. 2019. Comprehensive sustainability reporting in higher education institutions. Social Responsibility Journal 15: 155-70. [CrossRef]

Siboni, Benedetta, Carlotta Del Sordo, and Silvia Pazzi. 2013. Sustainability reporting in state universities: An investigation of Italian pioneering practices. International Journal of Social Ecology and Sustainable Development 4: 1-15. [CrossRef]

Son-Turan, Semen, and Wim Lambrechts. 2019. Sustainability disclosure in higher education. A comparative analysis of reports and websites of public and private universities in Turkey. International Journal of Sustainability in Higher Education 20: 1143-70. [CrossRef]

Trireksani, Terri, Yun-Ting Zeng, and Hadrian Djajadikerta. 2021. Extent of sustainability disclosure by Australian public universities: Inclusive analysis of key reporting media. Australian Journal of Public Administration 80: 830-48. [CrossRef]

Vagnoni, Emidia, and Caterina Cavicchi. 2015. An exploratory study of sustainable development at Italian universities. International Journal of Sustainability in Higher Education 16: 217-36. [CrossRef]

Vasilescu, Ruxandra, Cristina Barna, Manuela Epure, and Claudia Baicu. 2010. Developing university social responsibility: A model for the challenges of the new civil society. Procedia-Social and Behavioral Sciences 2: 4177-82. [CrossRef]

Yanez, Susana, Angel Uruburu, Ana Moreno, and Julio Lumberas. 2019. The Sustainability Report as an essential tool for the holistic and strategic vision of Higher Education Institutions. Journal of Cleaner Production 207: 57-66. [CrossRef]

Zorio-Grima, Ana, Laura Sierra-Garcia, and Maria Garcia-Benau. 2018. Sustainability reporting experience by universities: A causal configuration approach. International Journal of Sustainability in Higher Education 19: 337-52. [CrossRef] 